\title{
THE IMPACT OF TRANSLATORS' IDEOLOGY ON THE TRANSLATION PROCESS: A REACTION TIME EXPERIMENT
}

\author{
Ana Ma Rojo López \\ Universidad de Murcia (Spain) \\ anarojo@um.es \\ Marina Ramos Caro \\ Universidad de Murcia (Spain) \\ marinaramos@um.es
}

\begin{abstract}
This paper presents an experiment designed to measure the influence that a translator's political stance may exert on the time needed to find a translation solution when working with ideologically loaded concepts. To this purpose, a reaction time experiment (with positive and negative prompting conditions) was designed to evaluate whether words and expressions that are contrary to the translator's ideology may slow down the translation process, making translators take longer to find an adequate translation. Our hypothesis predicted that the reaction time of translators would be bigger when the English word was presented with a negative "prompt", that is, with a word they would feel contrary to their political views. Differences in reaction times between two groups of translators with different ideological viewpoints would provide empirical support for the claim that translators may be influenced by their ideological views. The results will contribute to increase translators' awareness of the impact that issues such as ideology and power may have on their work.
\end{abstract}

\section{Resumen}

Este trabajo presenta un experimento diseñado para medir la influencia que puede ejercer la postura política de un traductor sobre el tiempo que necesita para encontrar una solución de traducción cuando trabaja con conceptos con carga ideológica. Para ello, se diseñó un experimento de tiempo de reacción para determinar si palabras y 
expresiones contrarias a la ideología del traductor pueden decelerar el proceso de traducción, originando que el traductor tarde más en encontrar una solución adecuada. Nuestra hipótesis predecía que el tiempo de reacción de los traductores sería mayor cuando la palabra inglesa se presentara con un estímulo negativo, esto es, con una palabra contraria a sus convicciones políticas. Las diferencias en los tiempos de reaccción de dos grupos de traductores con perspectivas políticas dispares sustentaría empíricamente que los traductores pueden dejarse influir por su ideología. Los resultados pueden contribuir a profundizar la conciencia de los traductores del impacto de factores como la ideología y el poder en su trabajo.

Keywords: Translation process. Ideology. Reaction time.

Palabras clave: Proceso de traducción. Ideología. Tiempo de reacción.

Manuscript received on March 27, 2013 and accepted on September 25, 2013. 


\section{Defining the object of study: What do we understand by ideology?}

Ideology is indeed a most elusive concept. As in the case of the term equivalence, it is an everyday concept familiar to most laypeople, one of those terms that pervades our daily discussions but escapes an easy definition. Every ordinary citizen will probably recognize the term and be happy to use it without a hint of hesitation. But when asked what they really understand by ideology, they will most likely provide very different answers. Some may relate it to their political stance; others may use it to define their value-systems and worldviews; a few others may find it fervently tied up with their religious beliefs. The term is associated to sets of beliefs, assumptions, and values and this makes it, indeed, highly controversial.

At the time the term was first used by Count Destutt de Tracy, during the French Revolution, it adhered to the positive view of a new rationalist "science of ideas" which aimed to improve the living conditions of the population. However, from the 19th century onwards, social change did not quite evolve as planned and the term ideology started to acquire a sense of illusion and false consciousness, often associated with theoreticians who were out of touch with reality and fixed in their own dogmatic views. The term has ever since remained controversial despite the existence of contemporary uses that convey more neutral and scientific senses conveniently codified in intangible labels such as culture, worldview or mentalité (cf. Fawcett \& Munday 2011: 137). Unfortunately, once a negative image of a concept is formed, it is extremely hard to get rid of and a tone of disapproval has prevailed even in the most neutral senses of the term. On most occasions, the voice of the person using the term is accompanied by a ring of accusation that depends on the angle we look at things.

Apart from these controversial undertones associated with ideology, scholars from any discipline still have to solve the problem of defining the scope of the term. In translation, this problem becomes even more intricate due to the complexity of the task and the variety of factors and participants involved. The range of translation decisions that can be explained in terms of some sort of ideological intervention is not limited to the strategies adopted by the 
translator. The decisions of other participants, such as editors or commissioners, may also be ideologically biased, exerting a positive or negative influence on the image and impact of a translation in its target culture. One way to solve the problem is to provide a working definition specifically coined for the aims of each research project. By positing their own terminology and model, scholars can frame the notion of ideology in a more precise way, selecting the phenomena involved and discarding unwanted connotations.

In this article, we report on our attempt to measure the influence of the translator's ideology upon the time they need to find a translation. To this purpose, we provide a working definition of ideology to meet the specific requirements of our experimental design. We identified the translator's ideology by their position on a two-dimensional spectrum based on the correlation between their political views (towards the economic right or towards the left) and their social attitude (more or less authoritarian vs more or less libertarian). In very broad terms, translators are thus placed on the most right-wing and conservative part of the spectrum or on the most left-wing and liberal part. For the purposes of our research, each part is defined by a certain set of ideals and principles that explain how society should work in terms of a number of leading topics on most political agendas. Thus, right-wingers and conservatives are taken to support social order and traditional family and religious values; in general, they are often also seen as opposing abortion, sexual promiscuity, euthanasia, homosexuality, and illegal immigration. A large majority of right-wingers are also assumed to favor the death penalty for heinous crimes. On the contrary, left-wingers and liberals are often believed to support social change to create a more egalitarian society and also to favor, e.g., racial equality and open immigration, the right of women to choose abortion, the legal recognition of same-sex marriage, the abolition of the death penalty and the free distribution of contraceptives.

This ideological characterization is beyond any doubt an oversimplification of most people's social principles and moral beliefs. Our daily experience provides us with countless examples of individuals who adhere to some of these principles but not to others. There may be, for instance, right-wingers who support equal rights for homosexuals and left-wingers who oppose abortion for religious reasons; there may be conservatives who oppose the death penalty and open-minded people who may be against open immigration. Most people's ideological stance is far more complex than simple dichotomous thinking and it does not usually fit in political stereotypes and social typecasting. It is, therefore, important to bear in mind that, in our experiment, the above characterizations were used only as operational sets of parameters 
applied to select a range of issues that might contribute to establish a difference between the ideological stance of the informants.

\section{Ideology in translation studies: Filling the empirical gap}

Providing a precise picture of the role ideology has played in translation studies is also a thorny enterprise. Most of the studies on ideology have focused on exploring the essence and expression of ideological intervention in translation. The interest of translation studies in ideology has been shaped by the evolution of the discipline. The growing relevance and awareness of ideological aspects has been linked to the shift of the focus of research from the micro level of isolated linguistic units to the macro level of the socio-cultural context in which the translation act takes place. The "cultural turn" which translation studies experienced in the 1990s enforced the definite move from translation as text to translation as culture and politics (see Snell-Hornby 2006), placing ideological issues in the centre of the research agenda. Ideology has been since one of the key concerns of modern translation studies for the last two decades (Tymoczko 2003, 2007).

The interest of translation studies in ideology has been closely related to the relative power of the languages involved in translation acts. Since the first decade of the 21st century, much of the work carried out on ideology and power has focused on areas such as translation as rewriting, gender and translation, or translation and post-colonialism (see Baker 2010, Venuti 2000). The notion of "rewriting" (Lefevere 1992) relates the study of ideology to the way the source text and culture are manipulated or distorted when translating. From this perspective, the choices made during the translation process are assumed to be biased and the resulting translations are often seen as unavoidably partial representations of their source texts, thereby exerting a repressive or subversive impact on the target culture (see Fawcett \& Munday 2011: 138). Gender-focus work in translation interprets ideological aspects in terms of the sociopolitical connections between gender and language. Gender has been used as a powerful analytical tool at two different levels: at a macro-level, translations are revised with the aim of showing the role women and gender minorities (gays, bisexuals, lesbians, transexuals) have played in a given literary tradition. At a micro-level, translations have been examined to illustrate their sensitivity to manifestations of gender and to reveal the endeavor of writers, translators and researchers for the power to interpret meaning (see von Flotow 2011: 123-5). Postcolonial approaches to translation link the study of ideology to the question of how differences in the power of languages influence translation practices. With a special focus on European colonialism, they often are particularly interested in 
showing how translation might contribute to exposing and challenging colonialism in a postcolonial era (see Hui 2011: 200).

All these cultural and ideological issues have occupied a prominent position in translation studies in recent years, binding together a wide range of case studies mostly centered on literary translation. Nevertheless, and regardless of the specific research focus and the chosen approach, there has been a general concern for an increasing "interventionism" on the part of translators, a claim that requires greater awareness of the ideological values that may influence their job. As a consequence, questions often associated to ideology such as the translators' ethics, their relative position in the source or target culture and the inherent subjectivity and bias of their own ideological stance have also been placed in the centre of the research agenda. The scholars' interest in these questions and the way power differentials convey and frame ideology have resulted in an extensive number of publications on ideology and translation (e.g., von Flotow 2000; Tymozcko \& Gentzler 2002; Calzada 2003; Cunico \& Munday 2007).

Despite this abundance of studies and the claim for greater awareness of ideological aspects, to date there exists no empirical attempt to measure the influence of ideology on the translation process. The interesting question here is how the translator's ideology may be reflected in the translation process, even if expressed subconsciously (Munday 2007) and the fact that no study has been designed yet to test this empirically. In this sense, the present study aims to fill in such empirical gap by designing an experiment to measure the impact that the translators' ideological agenda may have on their translation processes in terms of the time needed to find an adequate translation.

\section{The impact of ideology on the translation process: A reaction time experiment based on "priming"}

As mentioned above, most of the work on ideology and translation has been carried out in critical essays which may adopt a more literary or linguistic point of view, but which tend to be far from the experimental field. Although the empirical aim of the work reported here may break new ground, the methods and instruments employed to measure the experimental variables have been used before in translation research. This study took as its starting point the work by Stamenov, Gerganov \& Popivanov (2010) on the benefits that the prompting technique may have on translating true and false cognates and non-cognates. The work by Stamenov and his colleagues combined the analysis of the participants' reaction times with their eye movements and percentage of correct answers in two different conditions-with and without 
prompting. The use of individual words as experimental stimuli facilitated the measurement of the participants' reaction times. By means of the moving window technique, a series of English words were projected on the screen of the eye tracker Tobii 1750 and participants were told to translate them into Bulgarian as quickly as possible. They first read the English word in the middle of the screen and 250 ms. later, the Bulgarian word appeared in the condition with prompt at about six degrees of visual angle above the English word. When the subjects thought they "knew" the translation, they pressed the Enter key and the screen went black so that they could type it. Once they had finished, they pressed Enter again to confirm it and signal the start of the next trial. Their results revealed no significant difference between the reaction times in the conditions with and without prompting, although prompting was shown to improve the translation in terms of percentage of correct answers.

The present study basically adheres to the methodology implemented by Stamenov, Gerganov \& Popivanov (2010) as a suitable benchmark to design an experiment to measure reaction times when researching the impact that a given ideological stance may have on the translation process. However, our experiment differs from that by Stamenov and colleagues in a few methodological issues. One of the main differences is that we used priming, instead of prompting, as an experimental technique. As explained by Stamenov et al. (2010), prompting differs from priming mainly in terms of their purpose: while priming is mostly used in psycholinguistic tasks to study the mental lexicon and sentence processing, prompting is developed as a tool to optimize the work of the translator. In the authors' own words, prompting is "a procedure that exploits priming effects for the benefit of accelerated translation recognition" (p. 329). A more detailed description of our experimental design follows.

\subsection{Aim and hypothesis}

There is evidence that compatible distractors typically facilitate responses to targets whereas incompatible distractors interfere with them (Botella et al. 2002). On the basis of these reported results, we hypothesized that words with a valence contrary to the translator's ideology would hinder their decisions, making them take longer to find an adequate translation. On the contrary, words consistent with the translator's ideology were expected to facilitate their decisions, making them take less time to find an adequate translation.

\subsection{Participants}

Sixteen people initially volunteered to participate in the experiment (8 males and 8 females). Although the number of participants is low for statistical 
analysis, the selection requirements of the experiment made it extremely hard to find suitable subjects. The translation task required at least high proficiency in English and Spanish, and the aim to explore ideological aspects demanded an ideological profile that the subjects were not always ready to reveal. For these reasons, we used a convenience sampling technique in which subjects were initially selected on the basis of their language proficiency as university teachers and/or their political affiliation and social attitudes. Selected participants were native speakers of Spanish with a high command of English. Fourteen of them had a degree in English or Translation and two had an advanced proficiency level of English accredited. At least five of them were affiliated to a political party. The rest of the participants were allocated into two different groups depending on their political views and social attitudes. To do so, the participants were asked to complete a political test available on the Web that allowed us to locate their position on a two-dimensional spectrum reporting on the correlation between the subjects' political views (economic right or left) and their social attitude (authoritarian or libertarian). Their position in relation to these two axes was defined in terms of some numerical coordinates, as in the example from one of our subjects shown in figure 1.

Economic Left / Right: -5.25

Social Authoritarianism / Anarchism: -5.44

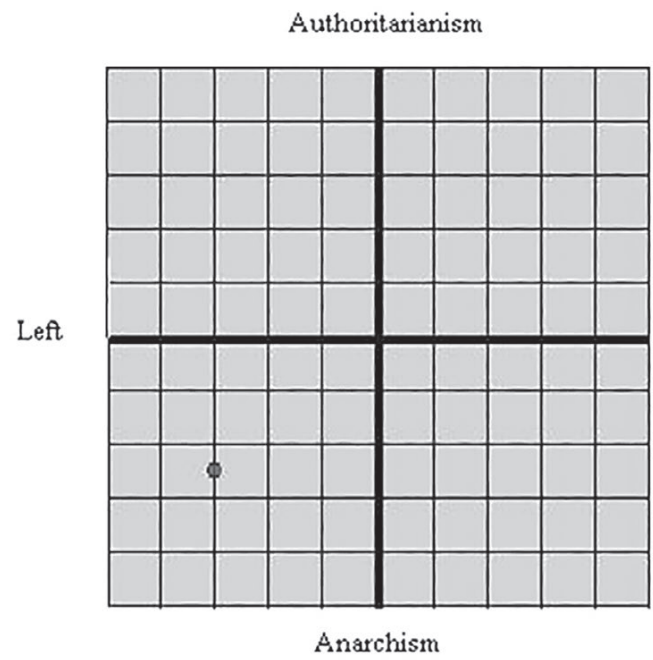

Right

Figure 1. Example of the spectrum to report on the correlation between political views and social attitudes. 
Quite surprisingly, all our subjects were located in the economic left and libertarian part of the spectrum (in the bottom left square of the diagram). For this reason, we selected the participants with the most extreme scores, i.e., those closest to either the top right or the bottom left corner of the bottom left square. The scoring scale ranged from 0 to \pm 10 , and only participants scoring less than \pm 4 o more than \pm 6 were selected. Two participants were rejected because they scored between these thresholds. Of the remaining twelve, six were classified as left-wingers and more libertarian and seven were categorized as right-wingeers and more authoritarian. It is important to note that this classification coincided with each subject's own categorization as a rightwinger or a left-winger, and as a more conservative and traditional citizen or more liberal and open-minded. One of the subjects in the conservative group was excluded later on, because she could not finish the experiment. We mention this case because the reasons for her to abandon the experiment support the hypothesis postulated in our work. As she explained to us, she had problems to translate most of the experimental stimuli because they were causing her an ideological conflict she did not know how to solve. She reported, for instance, that when translating the term "abortion", she felt "crime" would be the best description even if she knew it was not an adequate translation. At the end of this process, we were left with 6 participants in the "conservative" group and 6 in the "liberal" one. The age mean was 38.2 year-old (range 24 to 60 years).

\subsection{Design and instrument}

The program E-Prime was used to design a translation task based on a priming experiment with positive and negative priming conditions:

- The positive condition consisted in expressions primed by words that were potentially consistent with the subject's ideology

- The negative condition consisted in expressions primed by words that were potentially contrary to the subject's ideology

Inter-subject and an intra-subject comparisons were carried out to check not only whether there was a significant difference in the RTs obtained for each condition between both groups of subjects, but also whether each subject took longer to find a translation when the sentence was preceded by a prime contrary to their ideology. 


\subsection{Materials}

Fourteen English expressions were selected as the experimental stimuli the participants had to translate into Spanish. All the expressions were related to issues for which right- and left-wingers are considered to hold opposite views. Seven topics were selected, namely abortion, contraception, sex, euthanasia, death penalty, gay marriage, and immigration. Two expressions were crafted for each of these topics: for example, medical abortion and to end a pregnancy were chosen for the topic of abortion. Compound expressions were favored in order to increase the translation challenge. Two Spanish primes were also selected to introduce the expressions in each topic. For each topic there was a prime that was thought to convey a positive valence for right-wingers and a negative one for left-wingers; and another prime with opposing valences, that is, a negative one for right-wingers and a positive one for left-wingers. For instance, the expressions tested for the topic of abortion were introduced by crimen ('crime') as a term with a positive valence for right-wingers and libertad ('freedom') as a term with a positive valence for left-wingers. Table 1 displays the list of topics, experimental stimuli and primes.

32 other different expressions ( 16 for each condition) were also designed to act as distracting stimuli and mask the aim of the experiment. These expressions related to topics that were assumed not to be controversial from an ideological point of view (see appendix).

\subsection{Task and procedure}

Participants were asked to translate a series of English expressions into Spanish. They were provided the following instructions regarding the procedure of the experiment: ${ }^{1}$

A series of English sentences will be displayed on the computer screen. Each sentence contains an expression you must translate into Spanish. Read each sentence carefully and press "Enter" on the keyboard when you have understood it. Then, a Spanish term will appear in the middle of the screen and immediately after, you will be shown the English expression that must be translated into Spanish. Press "Enter" again when you think you know its translation into Spanish and then type the solution. When you finish, press "Enter" once more to start the following trial. You have first a practice session to get used to the procedure before the real experiment starts.

1. The participants received these instructions in Spanish. 
Each trial session consisted of 32 stimuli: 16 distractors + 28 experimental-14 with a positive prime for right-wingers and 14 with a positive prime for left-wingers (see appendix). They were presented in random order. The trial started with a short practice, to allow subjects to get used to the mechanics of the experiment.

\begin{tabular}{|c|c|c|c|}
\hline topic & stimuli & prime_r & prime_l \\
\hline \multirow{2}{*}{ abortion } & end a pregnancy & crimen & libertad \\
\hline \multirow{3}{*}{\begin{tabular}{c} 
contraception \\
\cline { 2 - 4 }
\end{tabular}} & medical abortion & crimen & libertad \\
\cline { 2 - 4 } & emergency contraception & asesinato & emancipación \\
\hline \multirow{3}{*}{ sex } & male masturbation & pecado & natural \\
\cline { 2 - 4 } euthanasia & sexual arousal & pecado & natural \\
\cline { 2 - 4 } & assisted suicide & homicidio & elección \\
\hline \multirow{3}{*}{ capital punishment } & death sentence & justicia & asesinato \\
\cline { 2 - 5 } & long-drop & justicia & asesinato \\
\hline \multirow{2}{*}{ gay marriage } & same-sex marriage & anti-natural & derecho \\
\cline { 2 - 5 } & gay adoption & anti-natural & derecho \\
\hline \multirow{2}{*}{ immigration } & Arabic headscarf & invasión & derecho \\
\cline { 2 - 5 } & immigrant Muslims & invasión & derecho \\
\hline
\end{tabular}

Table 1. Topics, experimental stimuli and positive primes for rightists and leftists.

To allow an intra-subject comparison, subjects had to translate the same expression twice: once with a positive prime (that is, consistent with their ideology) and once with a negative prime (that is, inconsistent with their ideology). Although the experimental stimuli (the phrases) were the same for the two conditions, the sentences where they were embedded were slightly different in each condition to prevent the subjects from not reading the sentence carefully the second time they were presented with the same expression. In order to minimize order effects, half of the stimuli were presented first with a positive prime and then with a negative one whereas the other half was 
shown in the opposite order (i.e., first with a negative prime and then with a positive one).

As in the work by Stamenov and his colleagues, the primes were presented in the participants' mother tongue. It was assumed that giving the primes to the participants in their native tongue (which was also the language they were translating into) increased the facilitating or impeding effect that the primes might have on the participants' ability to find a translation. However, the procedure we used to introduce the primes differed. While in Stamenov, Gerganov \& Popivanov (2010) the prompt remained on the screen at about six degrees of visual angle above the word to be translated, in our experiment primes were introduced after the subject pressed the Enter key and appeared in the middle of the screen for about $1250 \mathrm{~ms}$. Then they disappeared and were replaced by the expression to be translated. The reason for this change was the feedback from several subjects during a pilot trial. This pilot trial used the prompting technique designed by Stamenov and his colleagues, keeping the prompt on the screen above the expression to be translated, but the subjects declared that after a couple of examples, they completely ignored the prompt, and sometimes they even made a conscious effort not to look at it. We then decided to use an alternative method that would force them to read the prime, by displaying it on the screen before the experimental stimulus.

Figures 2 and 3 below exemplify step by step the experimental procedure for the two different contexts designed to translate the expression medical abortion with the two different primes (one with a conservative valence, and one with a liberal one). First, participants read a sentence in English that contained the expression they would have to translate later on in Spanish
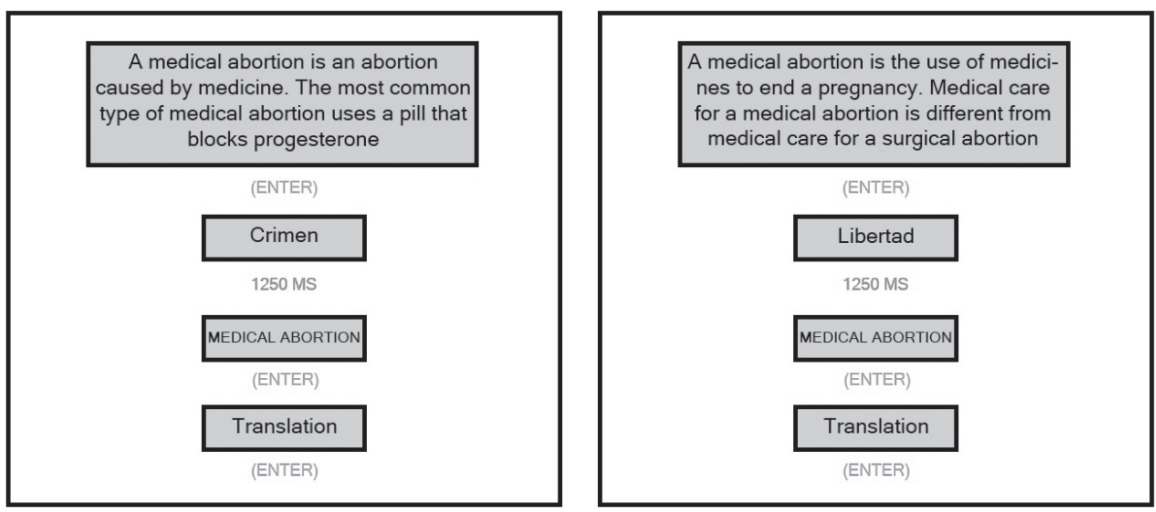

Figures 2 and 3. Examples of the experimental procedure with the two different contexts and primes designed for the same expression. 
(medical abortion, in figures 2 and 3). Once they had understood the sentence, they had to press Enter and the Spanish prime would appear in the middle of the screen for about $1250 \mathrm{~ms}$. Once the prime had disappeared automatically, the English expression to be translated appeared in capital letters on the screen. When they considered they knew the translation, they had to press Enter again and type the translation. Then, they would press Enter again to proceed to the next round.

\subsection{Results}

To calculate the participants' reaction times, we used the computer's timestamp of the moment the participants pressed Enter when they thought they knew the translation for the English expression they had to render into Spanish. In this way, we avoided individual differences in the typing speed of the participants as well as other problems related to the typing of the translation on the keyboard, such as deletions and rewritings that the program could not record, but which could have increased the final time the participant took to provide a translation.

One of the major problems we faced to analyze our data was related to the differences between the experimental stimuli. After all, we were dealing with the translation of expressions that, despite our efforts to homogenize them as much as possible, were still likely to differ as to the level of difficulty that they posed for the subjects (both in terms of understanding and reformulating). For this reason, instead of using raw reaction times to perform the statistical analysis, our results were standardized to make them more comparable. The mean reaction time was, therefore, calculated for each stimulus in order to compute the difference between this mean and the times of each participant (a positive number was obtained when they were slower than the mean, and a negative one when they were faster). Once we had established how much each participant deviated from the mean in every stimulus, we eliminated outliers that were more than two standard deviations from the mean. In this way, the differences between the stimuli were minimized, increasing the potential of the data for statistical comparison.

The descriptive statistical tests showed that our results followed, for the most part, a normal distribution. Table 2 shows that the tests of normality yielded acceptable results for both primes and ideological groups, with the only exception of the value obtained for the negative prime in the right-wing group $(<.05)$. 
Tests of Normality

\begin{tabular}{|c|c|c|c|c|c|c|c|}
\hline & \multirow[b]{2}{*}{ Ideology } & \multicolumn{3}{|c|}{ Kolmogorov-Smirnov ${ }^{a}$} & \multicolumn{3}{|c|}{ Shapiro-Wilk } \\
\hline & & Statistic & df & Sig. & Statistic & $\mathrm{df}$ & Sig. \\
\hline \multirow[t]{2}{*}{ Positive Prime } & left-wing & ,251 & 6 & ,200* & ,906 & 6 &, 413 \\
\hline & right-wing &, 260 & 6 &, $200^{*}$ & ,881 & 6 & ,273 \\
\hline \multirow[t]{2}{*}{ Negative Prime } & left-wing &, 160 & 6 &, $200^{*}$ & 934 & 6 & 609 \\
\hline & right-wing & ,290 & 6 & ,124 & ,744 & 6 & ,018 \\
\hline
\end{tabular}

Table 2. Values for normality tests.

Nevertheless, the tests to check both the asymmetry and the kurtosis of the distribution yielded acceptable results for asymmetry, the anomalous values being only referred to kurtosis parameters. The test of homogeneity of variance displayed in table 3 also offered acceptable results for both positive and negative primes.

Test of Homogeneity of Variance ${ }^{a}$

\begin{tabular}{llrrrr}
\hline \hline & Levene Statistic & df1 & df2 & \multicolumn{1}{c}{ Sig. } \\
\hline Positive Prime & Based on Mean & 2,160 & 1 & 10 &, 172 \\
& Based on Median & 1,849 & 1 & 10 &, 204 \\
& $\begin{array}{l}\text { Based on Median and with } \\
\text { adjusted df }\end{array}$ & 1,849 & 1 & 9,600 &, 205 \\
& Based on trimmed mean & 2,150 & 1 & 10 &, 173 \\
\hline Negative Prime & Based on Mean & 3,876 & 1 & 10 &, 077 \\
& Based on Median & 3,391 & 1 & 10 &, 095 \\
& Based on Median and with & 3,391 & 1 & 5,373 &, 121 \\
& adjusted df & & & &, 078 \\
\hline \hline a. Version Exp = B & Based on trimmed mean & 3,861 & 1 & 10 & \\
\end{tabular}

Table 3. Values for homogeneity of variance.

The general asymmetry of the distribution is also illustrated in figure 4, which shows an acceptable symmetrical parting of the figures for both primes and ideological viewpoints.

As can be seen in table 4 below, a repeated measures ANOVA test showed a significant effect for type of prime $(F(1,10)=5.57$; $<<0.05)$. This result supports that reading a prime with a valence that agreed or disagreed with the ideological values of the participants had an impact on the time they took to find an adequate translation, regardless of the particular ideology they 

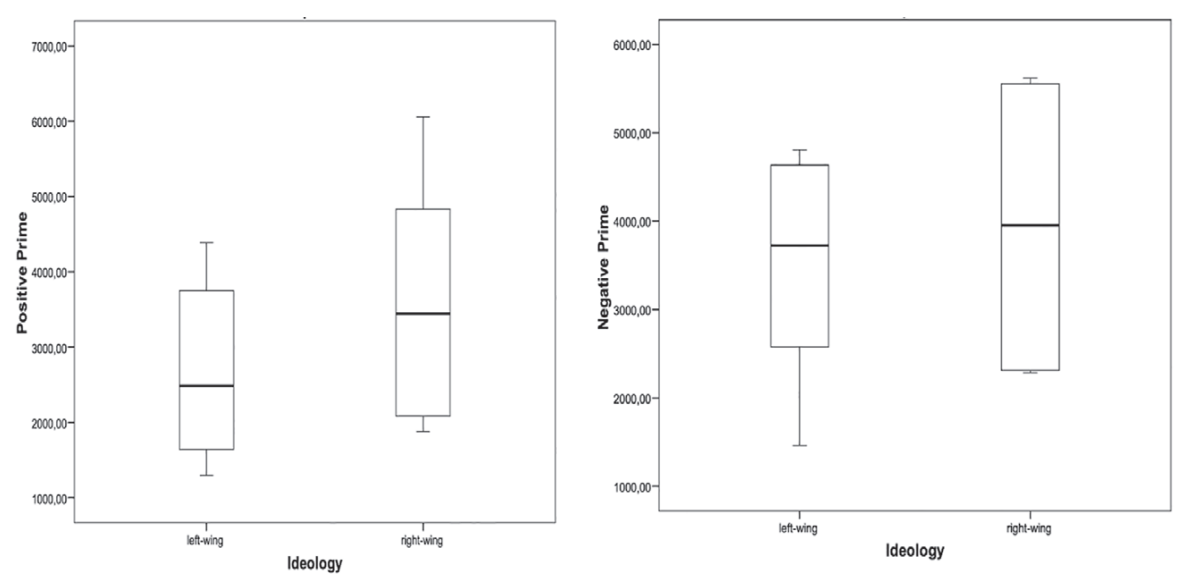

Figure 4. Results of tests of normality and homogeneity of variance.

subscribed to. The effect for the interaction between prime and ideology was not statistically significant $(F(1,11)=3.99 ; \mathrm{p}=0.074)$, although a value of $\mathrm{p}$ $=0.07$ shows a tendency towards statistical significance. This result suggests that, although we cannot definitely state that the effect of meeting a positive or a negative prime is different for each ideological group, there is certainly a tendency that points to the existence of differences. Let us here remember that both groups were actually the extreme right and extreme left subgroups within the +left, +anarchism area. We will return to this point below.

Tests of Within-Subjects Contrasts ${ }^{b}$

Measure: MEASURE_1

\begin{tabular}{llcrrrrrr}
\hline \hline Source & prime & $\begin{array}{c}\text { Type III Sum of } \\
\text { Squares }\end{array}$ & df & & Mean Square & $F$ & Sig. & \multicolumn{2}{c}{$\begin{array}{c}\text { Noncent. } \\
\text { Parameter }\end{array}$} & Observed Power $^{{ }^{a}}$ \\
\hline prime & Linear &, 059 & 1 &, 059 & 5,578 &, 040 & 5,578 &, 568 \\
\hline prime * Ideology & Linear &, 042 & 1 &, 042 & 3,992 &, 074 & 3,992 &, 439 \\
\hline Error(prime) & Linear &, 106 & 10 &, 011 & & & & \\
\hline \hline a. Computed using alpha $=, 05$ &
\end{tabular}

Table 4. Results for type of prime and for the intersection between prime and ideology.

This tendency becomes more obvious in figure 5 , which clearly illustrates the different behavior of both groups (left-wingers represented by a dotted line and right-wingers by a continuous line) for each of the primes (positive $=1$, negative $=2$ ). The figure shows a patent difference in the way the most liberal group responded to a prime consistent with their ideology in comparison to 


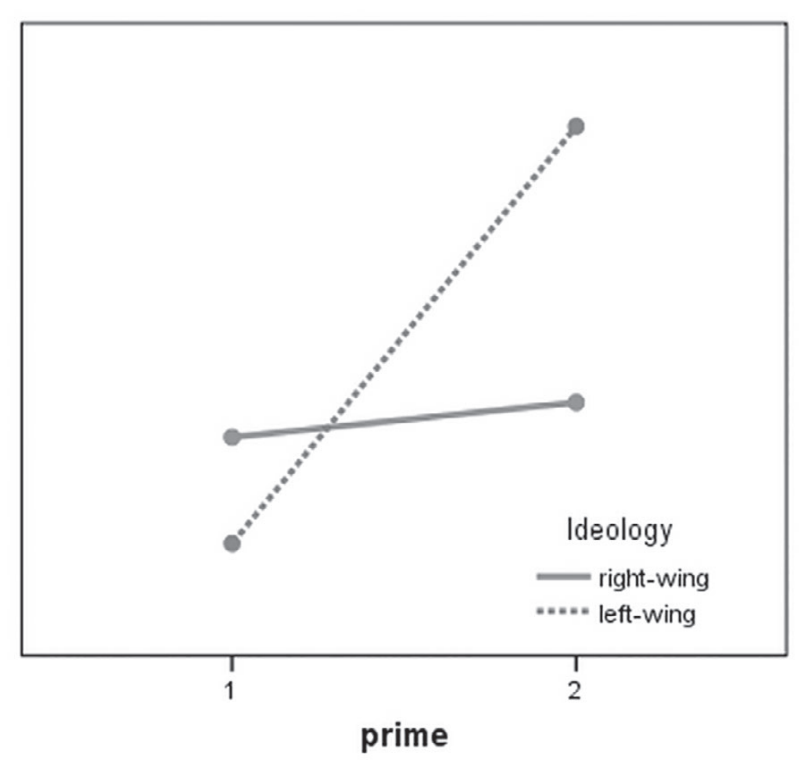

Figure 5. Effects for type of prime and ideological group.

their response when they read a prime opposing their ideological values. On the contrary, the most conservative group showed overall a more homogeneous behavior with both types of primes. ${ }^{2}$ Although figure 5 seems to point to a general difference in time between the two groups, the results displayed in table 5 below reveal that ideology on its own was not found to have a significant effect on the subjects' reaction times $(F(1,10)=0.35 ; \mathrm{p}=0.85)$.

Tests of Between-Subjects Effects ${ }^{b}$

Measure: MEASURE_1

Transformed Variable: Average

\begin{tabular}{lcrrrrrr}
\hline \hline Source & $\begin{array}{c}\text { Type III Sum of } \\
\text { Squares }\end{array}$ & df & & Mean Square & F & Sig. & \multicolumn{2}{c}{$\begin{array}{c}\text { Noncent. } \\
\text { Parameter }\end{array}$} & Observed Power $^{\text {O }}$ \\
\hline Intercept & 2,041 & 1 & 2,041 & 8,660 &, 015 & 8,660 \\
Ideology &, 008 & & 1 &, 008 &, 035 &, 855 &, 035 \\
Error & 2,357 & 10 &, 236 & & &, 053 \\
\hline \hline a. Computed using alpha $=, 05$ & & & & & & \\
\hline
\end{tabular}

Table 5. Results for ideology.

2. Reaction times are not displayed on the vertical axis of the diagram because results were based on standardized measures. 
In fact, if the response of right-wingers and left-wingers to positive primes was quite similar, their reaction to negative primes was much more differentiated, which somehow neutralized the overall difference between the groups. This result is rather encouraging from the point of view of the translation profession since it indicates that the participants' ideological stance was not affecting the time they needed to provide a translation.

\section{General discussion and conclusions}

The results from our experiment corroborate the postulated hypothesis, and provide evidence that the type of prime exerts a significant influence on the time participants take to find a suitable translation. Words with a valence contrary to the participants' ideological viewpoint elicited longer reaction times than words that were consistent with their beliefs. This effect was found for all participants, independently of their ideological stance.

When we compared the effect that the type of prime had on each group of participants, we did not find a significant effect of the intersection between prime and ideology. However, the fact that our results were closer to statistical significance points to the existence of differences between the effect that different primes may have on each ideological group. Our data revealed that those participants with a more libertarian ideology were much faster when they read a word that was consistent with their beliefs than when they read one which was contrary to their ideological values. On the contrary, the participants with a more conservative ideology were also slightly slower when the word was contrary to their beliefs, but the difference with the positive prime condition was much smaller and did not reach statistical significance, showing a more homogeneous behavior with both types of primes.

A possible explanation for the different behavior of both groups may be found in the moderate attitude of our conservative subjects. As the results of the political test indicated, none of our participants could be classified as really authoritarian and conventional; in fact, most of them could not even be classified as radical right-wingers either. These results were more surprising if we take into account that some of our participants hold strong religious values and were affiliated to right-wing political parties. One could argue that the results of the political test were not reliable enough, but our inteaction with the subjects gave us further indication of the complexity of factors involved. Even those subjects who classified themselves as right-wingers showed a more tolerant attitude towards some of the topics involved in the design of the experiment. Some right-wingers, for instance, declared themselves in 
favor of same-sex marriage and some had a permissive attitude towards sex and the use of contraceptives.

The global tendency of modern society towards a more libertarian and tolerant attitude could very well be one of the factors that interferes in our results. It is possible that our participants' reaction is affected by the political system and social practices of the country they live in. In Spain, nowadays, it is probably more shocking for a left-winger to hear that same-sex marriage is "anti-natural" than for a right-winger to hear it is a "right". There are besides a wide range of cultural factors that could also be playing a part in our results. For instance, even if Spain is a country currently governed by a right-wing party, our recent political history has been marked by shades of left. Living in a country where abortion and gay marriage are legal and where open immigration has become a constant in our daily life could be moderating our right-wingers' attitudes towards some of the topics included in the experiment. Unfortunately, this assumption is at this stage a mere speculation that would certainly need further thought and study.

In any case, and whether the effect reported in our experiment has or not a cultural basis, the fact is that the difference in the reaction times of subjects when confronted with words that agree or disagree with their ideological beliefs indicates that the translator's ideology may exert an influence on their job. Fortunately, this influence is not a compelling "a priori" force that drives the translator's job in a certain direction. Rather, our data suggest that the subjects' ideology does not exert per se a significant influence on the time they take to find a suitable translation. In other words, the fact that subjects have a certain ideological profile does not make them translate slower or faster. Only when subjects meet a word or expression that may challenge their ideological expectations do these expectations become a force that may exert an influence on their translations.

The results of our experiment suggest that this influence exists at least in terms of the time needed to provide an adequate translation. They also open interesting venues for future research on the topic. Further experiments could be designed to investigate the impact of ideology on production, exploring the translator's preferences for certain terms and stylistic choices. Additionally, the role translation expertise plays in controlling subjectivity would also be an appealing area for future experimental research. If expert translators are shown to control their subjectivity better than novices, this type of research could have pedagogical implications of practical use in translation training. Translation courses could be designed to teach students to control their 
subjectivity, making them aware of the consequences that unrestrained ideological bias may have for their work.

If anything, the experiment suggested here could contribute to widening the spectrum of works on ideology and translation. Opening new ground for experimental research on ideological factors could certainly provide additional information on the impact these factors may have on cognitive translation processes. This type of experimental work would no doubt play a role in the diversification of research methods, adding to traditional empirical and theoretical work in the field.

\section{References}

BAKER, Mona. (2010) Critical Readings in Translation Studies. London: Routledge. Botella, Juan; María Isabel Barriopedro \& James F. Joula. (2002) “Temporal interactions between target and distractor processing: Positive and negative priming effects". Psicológica 23, pp. 371-400.

Calzada PÉREZ, María. (2003) Apropos of Ideology —Translation Studies on Ideology -Ideologies in Translation Studies. Manchester: St. Jerome.

CuniCO, Sonia \& Jeremy Munday, (eds.) (2007) Translation and Ideology: Encounters and Clashes. Special Issue of the Translator 13:2.

FAWCETT, Peter \& Jeremy Munday. (2011) "Ideology." In: Baker, Mona \& Gabriela Saldanha (eds.) 2011. The Routledge Encyclopedia of Translation Studies. 2nd edition. Abingdon: Routledge, pp. 137-140.

Tyмoсzko, Maria \& Edwin Charles Gentzler. (2002) Translation and Power. Amherst, MA: University of Massachusetts.

HUI, Wang. (2011) "Postcolonial approaches." In: Baker, Mona \& Gabriela Saldanha (eds.) 2011. The Routledge Encyclopedia of Translation Studies. 2nd edition. Abingdon: Routledge, pp. 200-204.

LefEVERE, André. (1992) Translation, Rewriting and the Manipulation of Literary Fame. London: Routledge.

MunDAY, Jeremy. (2007) Style and Ideology in Translation. Latin American Writing in English. New York: Routledge.

Snell-Hornby, Mary. (2006) The Turns of Translation Studies. New paradigms or shifting viewpoints? Amsterdam: John Benjamins.

Stamenov, Maxim; Alexander Gerganov \& Ivo Popivanov. (2010) "Prompting cognates in the bilingual lexicon: Optimizing access during translation." In: Shreve, Gregory \& Erik Angelone (eds.) 2010. Translation and Cognition. Amsterdam: John Benjamins, pp. 323-347.

TYMoczko, Maria. (2003) "Ideology and the position of the translator: In what sense is a translator 'in-between'?". In: Calzada Pérez, María (ed.) 2003. 
Apropos of Ideology. Translation Studies on Ideology -Ideologies in Translation Studies. Manchester: St. Jerome, pp. 181-201.

Tyмосzко, Maria. (2007) Enlarging Translation, Empowering Translators. Manchester: St. Jerome.

Venuti, Lawrence. (2000) The Translation Studies Reader. London: Routledge.

vON Flotow, Luise. (2011) "Gender and sexuality." In: Baker, Mona \& Gabriela Saldanha (eds.) 2011. The Routledge Encyclopedia of Translation Studies. 2nd edition. Abingdon: Routledge, pp. 123-126.

VON FlOTOW, Luise. (2000) "Women, bibles, ideologies." TTR: Traduction, Terminologie, Rèdaction 13: 1, pp. 9-20.

\section{Appendix}

\section{EXPERIMENTAL STIMULI}

\begin{tabular}{|c|c|c|}
\hline SENTENCE & PRIME & EXPRESSIONS \\
\hline $\begin{array}{l}\text { One of the most important public policy debates today surrounds } \\
\text { the issues of euthanasia and assisted suicide. }\end{array}$ & homicidio & \multirow[b]{2}{*}{ assisted suicide } \\
\hline $\begin{array}{l}\text { Not many people sit on the fence on the issue of euthanasia } \\
\text { or assisted suicide-most have fairly strong beliefs that they're } \\
\text { either morally right or morally wrong. }\end{array}$ & elección & \\
\hline Iran Imposes Death Sentence on U.S. Man Accused of Spying & justicia & \multirow[b]{2}{*}{ death sentence } \\
\hline $\begin{array}{l}\text { Judge's reasons for imposing death sentence in deputy killing } \\
\text { case }\end{array}$ & asesinato & \\
\hline $\begin{array}{l}\text { Emergency contraception can be started up to } 120 \text { hours-five } \\
\text { days-after unprotected intercourse. The sooner it is started, the } \\
\text { better it works. }\end{array}$ & emancipación & \multirow{2}{*}{$\begin{array}{l}\text { emergency } \\
\text { contraception }\end{array}$} \\
\hline $\begin{array}{l}\text { Emergency contraception is a birth control option that women } \\
\text { can use to reduce the risk of pregnancy after unprotected sex. }\end{array}$ & asesinato & \\
\hline $\begin{array}{l}\text { An abortion is a procedure to end a pregnancy. It uses medicine } \\
\text { or surgery to remove the embryo or fetus and placenta from the } \\
\text { uterus. }\end{array}$ & crimen & \multirow{2}{*}{ end a pregnancy } \\
\hline $\begin{array}{l}\text { A spontaneous abortion occurs when the fetus stops growing and } \\
\text { the body expels it. An induced abortion occurs when a woman } \\
\text { chooses to end a pregnancy. }\end{array}$ & libertad & \\
\hline $\begin{array}{l}\text { A } 2006 \text { poll by the Pew Research Center found a close divide on } \\
\text { gay adoption among the United States public }\end{array}$ & derecho & \multirow{2}{*}{ gay-adoption } \\
\hline $\begin{array}{l}\text { Mitt Romney used a recent one-on-one interview with WBTV as } \\
\text { an opportunity to clarify his position on gay adoption. }\end{array}$ & antinatural & \\
\hline $\begin{array}{l}\text { Immigrant Muslims are ethnically extremely varied, coming } \\
\text { from virtually every country where Muslims live, or well over } \\
100 \text { countries in all. }\end{array}$ & oportunidad & \multirow{2}{*}{$\begin{array}{l}\text { immigrant } \\
\text { Muslims }\end{array}$} \\
\hline $\begin{array}{l}\text { Immigrant Muslims come from a variety of ethnic, linguistic, and } \\
\text { cultural back-grounds and they tend to live in groups formed on } \\
\text { the basis of ethnic, cultural, and social origins. }\end{array}$ & invasión & \\
\hline
\end{tabular}




\begin{tabular}{|c|c|c|}
\hline $\begin{array}{l}\text { Muslim girls wear the Islamic headscarf in Spanish schools } \\
\text { because they consider it an act of respect before God, and } \\
\text { because they feel good wearing it. }\end{array}$ & invasión & \multirow{2}{*}{$\begin{array}{l}\text { Islamic } \\
\text { headscarf }\end{array}$} \\
\hline $\begin{array}{l}\text { Muslim women wear the Islamic headscarf in Spain because it is } \\
\text { a mark of dignity and respect before God. }\end{array}$ & oportunidad & \\
\hline $\begin{array}{l}\text { The long drop is a method of hanging in which the person's } \\
\text { height and weight were used to determine how much slack } \\
\text { would be provided in the rope so that the distance dropped } \\
\text { would be enough to ensure that the neck was broken. }\end{array}$ & asesinato & \multirow{2}{*}{ long drop } \\
\hline $\begin{array}{l}\text { The modern method of judicial hanging is called the long drop, } \\
\text { in which those planning the execution calculate the drop dis- } \\
\text { tance required to break the subject's neck based on his or her } \\
\text { weight, height and build. }\end{array}$ & justicia & \\
\hline $\begin{array}{l}\text { The most common male masturbation technique is simply to } \\
\text { hold the penis with a loose fist and then to move the hand up } \\
\text { and down the shaft. }\end{array}$ & pecado & \multirow{2}{*}{$\begin{array}{c}\text { male } \\
\text { masturbation }\end{array}$} \\
\hline $\begin{array}{l}\text { Male masturbation techniques are numerous; add a sex toy to the } \\
\text { mix and the male masturbation techniques never end. }\end{array}$ & natural & \\
\hline $\begin{array}{l}\text { A medical abortion is an abortion caused by medicine. The } \\
\text { most common type of medical abortion uses a pill that blocks } \\
\text { progesterone. }\end{array}$ & libertad & \multirow{2}{*}{$\begin{array}{l}\text { medical } \\
\text { abortion }\end{array}$} \\
\hline $\begin{array}{l}\text { A medical abortion is the use of medicines to end a pregnancy. } \\
\text { Medical care for a medical abortion is different from medical care } \\
\text { for a surgical abortion. }\end{array}$ & crimen & \\
\hline $\begin{array}{l}\text { You need to use the morning-after pill to prevent pregnancy after } \\
\text { each time you have unprotected intercourse. }\end{array}$ & asesinato & \multirow{2}{*}{$\begin{array}{l}\text { morning-after } \\
\text { pill }\end{array}$} \\
\hline $\begin{array}{l}\text { The morning-after pill stops you from becoming pregnant, after } \\
\text { unprotected sex. }\end{array}$ & emancipación & \\
\hline $\begin{array}{l}\text { Physician aid-in-dying is the choice of mentally competent, ter- } \\
\text { minally ill, adult patients to ask their doctors for medication to } \\
\text { bring about a peaceful death }\end{array}$ & elección & \multirow{2}{*}{$\begin{array}{l}\text { physician } \\
\text { aid-in-dying }\end{array}$} \\
\hline $\begin{array}{l}\text { Physician aid-in-dying refers to a practice in which a physician } \\
\text { provides a terminally ill patient with a prescription for a lethal } \\
\text { dose of medication, upon the patient's request. }\end{array}$ & homicidio & \\
\hline $\begin{array}{l}\text { In recent years, the debate over same-sex marriage has grown } \\
\text { into a nationwide controversy. }\end{array}$ & antinatural & \multirow[b]{2}{*}{$\begin{array}{l}\text { same-sex } \\
\text { marriage }\end{array}$} \\
\hline $\begin{array}{l}\text { A news report from CTV showed that a growing number of Con- } \\
\text { servatives were wary about re-opening the debate over same-sex } \\
\text { marriage. }\end{array}$ & derecho & \\
\hline $\begin{array}{l}\text { Sexual arousal is our body's response to sexual stimulation. We } \\
\text { may become aroused by things we hear, see, smell, taste, or } \\
\text { touch. }\end{array}$ & natural & \multirow{2}{*}{ sexual arousal } \\
\hline $\begin{array}{l}\text { Sexual arousal has several stages and may not lead to any actual } \\
\text { sexual activity, beyond a mental arousal and the physiological } \\
\text { changes that accompany it. }\end{array}$ & pecado & \\
\hline
\end{tabular}




\section{DISTRACTORS}

\begin{tabular}{|c|c|c|}
\hline SENTENCE & PRIME & EXPRESSIONS \\
\hline $\begin{array}{l}\text { The ascent of creative writing, particularly in an age dominated } \\
\text { by the impatient pursuit of visual stimulation, might seem hard } \\
\text { to explain. }\end{array}$ & aficción & \multirow{2}{*}{ creative writing } \\
\hline $\begin{array}{l}\text { The ascent of creative writing programs means that few with } \\
\text { critical ability have any incentive to rock the boat--awards and } \\
\text { jobs may be held back in retaliation. }\end{array}$ & terapia & \\
\hline $\begin{array}{l}\text { Hurricanes are massive tropical cyclonic storms with winds } \\
\text { exceeding } 119 \mathrm{~km} / \mathrm{hr} \text { ( } 74 \text { miles/hour). }\end{array}$ & desastre & \multirow[b]{2}{*}{ cyclonic storms } \\
\hline $\begin{array}{l}\text { Although cyclonic storms are generally well forecast by } \\
\text { modern weather forecasting models, the same is not so true of } \\
\text { the details within them. }\end{array}$ & destrucción & \\
\hline $\begin{array}{l}\text { A few decades ago, glamorous events held both genders to high } \\
\text { standards of elegance. A woman in a floorlength dress would } \\
\text { parade on the arm of a man in an impeccable tuxedo. }\end{array}$ & sofisticación & \multirow[b]{2}{*}{ elegance } \\
\hline $\begin{array}{l}\text { Regardless of time and put, standards of elegance are always } \\
\text { there. However, media representations are allowing young } \\
\text { women unattainable beauty ideals which are destroying the self } \\
\text { esteem regarding young girls and women. }\end{array}$ & simplicidad & \\
\hline $\begin{array}{l}\text { This site includes information about conservation efforts and } \\
\text { endangered species organizations that are dedicated to saving } \\
\text { and preserving the world's most endangered wildlife and plant } \\
\text { life. }\end{array}$ & selva & \multirow[t]{2}{*}{$\begin{array}{l}\text { endangered } \\
\text { wildlife }\end{array}$} \\
\hline $\begin{array}{l}\text { When endangered wildlife is studied, quite often it is only the } \\
\text { animals which are considered. }\end{array}$ & animals & \\
\hline $\begin{array}{l}\text { Greenhouse gases are called so because they cause the } \\
\text { greenhouse effect by absorbing the infra red rays and do not } \\
\text { allow these rays to escape the atmosphere of the earth }\end{array}$ & contaminación & \multirow{2}{*}{$\begin{array}{l}\text { greenhouse } \\
\text { gases }\end{array}$} \\
\hline $\begin{array}{l}\text { Greenhouse gases are harmful to our environment not only } \\
\text { because they increase the temperature of our planet, but } \\
\text { because they are also a major source of air pollution. }\end{array}$ & limpieza & \\
\hline $\begin{array}{l}\text { A holiday resort is a place used for relaxation or recreation, } \\
\text { attracting visitors for holidays or vacations. }\end{array}$ & holgazanería & \multirow[b]{2}{*}{ holiday resort } \\
\hline $\begin{array}{l}\text { A holiday resort is a great example of well thought-out design; } \\
\text { a successful combination of a hotel and a holiday home. A } \\
\text { holiday resort has just about everything that a family's holiday } \\
\text { heart could desire. }\end{array}$ & relax & \\
\hline $\begin{array}{l}\text { Horror Films are unsettling films designed to frighten and } \\
\text { panic, cause dread and alarm, and to invoke our hidden worst } \\
\text { fears, often in a terrifying, shocking finale. }\end{array}$ & realidad & \multirow{2}{*}{ horror films } \\
\hline $\begin{array}{l}\text { Horror Films are a film genre seeking to elicit a negative } \\
\text { emotional reaction from viewers by playing on the audience's } \\
\text { most primal fears. }\end{array}$ & ficción & \\
\hline
\end{tabular}




\begin{tabular}{|c|c|c|}
\hline $\begin{array}{l}\text { Personality disorders are a class of personality types and } \\
\text { enduring behaviors associated with significant distress or } \\
\text { disability, which appear to deviate from social expectations } \\
\text { particularly in relating to others. }\end{array}$ & medicina & \multirow[t]{2}{*}{$\begin{array}{l}\text { personality } \\
\text { disorders }\end{array}$} \\
\hline $\begin{array}{l}\text { Personality Disorders are signified by behaviors and inner } \\
\text { experiences that deviate from the culturally acceptable norms. }\end{array}$ & psiquiatría & \\
\hline $\begin{array}{l}\text { Pet adoption usually refers to the process of taking guardianship } \\
\text { of and responsibility for a pet that a previous owner has } \\
\text { abandoned }\end{array}$ & caridad & \multirow[b]{2}{*}{ pet adoption } \\
\hline $\begin{array}{l}\text { In North America millions of lost, stray, and abandoned } \\
\text { animals enter shelters every available, pet adoption is quickly } \\
\text { becoming the most popular year. With so many animals } \\
\text { method of finding a new pet. }\end{array}$ & compañía & \\
\hline $\begin{array}{l}\text { Tropical rainforest plants would exceed the number of plant } \\
\text { species found all over the world. The warm climate of rainforest } \\
\text { with high levels of moisture supports almost } 80 \% \text { of the world's } \\
\text { biodiversity. }\end{array}$ & vegetación & \multirow[t]{2}{*}{ rainforest plants } \\
\hline $\begin{array}{l}\text { Some tropical rainforest plants are carnivorous, or meat-eating. } \\
\text { They have a cavity filled with either sweet or terrible smelling } \\
\text { nectar that attracts insects, especially ants and flies. }\end{array}$ & desierto & \\
\hline $\begin{array}{l}\text { Throughout cinematic history, especially in science-fiction } \\
\text { tales, robots have always played a primary role. }\end{array}$ & realidad & \multirow{2}{*}{$\begin{array}{l}\text { science-fiction } \\
\text { tales }\end{array}$} \\
\hline $\begin{array}{l}\text { The book offers six short science-fiction tales with a retro flair, } \\
\text { often featuring a mysterious female time agent. These stories } \\
\text { deal with romance, mystery, time travel and other dimensions. }\end{array}$ & ficción & \\
\hline $\begin{array}{l}\text { A recent study found that women increased their purchase } \\
\text { intentions by more than } 200 \text { percent when the models in the } \\
\text { mock ads were their size. }\end{array}$ & delgadez & \multirow{2}{*}{ size } \\
\hline $\begin{array}{l}\text { Recent research shows that women are actually much more } \\
\text { willing to buy an item that's modeled by someone closer to } \\
\text { their own size. }\end{array}$ & obesidad & \\
\hline $\begin{array}{l}\text { The } 2009 \text { flu pandemic or swine flu was an influenza pandemic, } \\
\text { and the second of the two pandemics involving HINl influenza } \\
\text { virus }\end{array}$ & enfermedad & \multirow{2}{*}{ swine flu } \\
\hline $\begin{array}{l}\text { In } 1998 \text {, swine flu was found in pigs in four U.S. states. Within } \\
\text { a year, it had spread through pig populations across the United } \\
\text { States. }\end{array}$ & curación & \\
\hline $\begin{array}{l}\text { Voice-over is a production technique where a voice that is not } \\
\text { part of the narrative is used in a radio, television production, } \\
\text { filmmaking, theatre, or other presentations. }\end{array}$ & trabajo & \multirow[t]{2}{*}{ voice-over } \\
\hline $\begin{array}{l}\text { A voice over is a narration technique in which an actor's lines } \\
\text { are heard over the visuals in a movie or commercial. }\end{array}$ & traducción & \\
\hline $\begin{array}{l}\text { Rushing waterfalls, steep slopes, } 10 \text { species of primates and } \\
\text { a wealth of unique bird and plant species are the highlights } \\
\text { of hiking in the seldom-visited Udzungwa Mountains, in } \\
\text { Tanzania. }\end{array}$ & vacaciones & \multirow[t]{2}{*}{ waterfalls } \\
\hline $\begin{array}{l}\text { In Niagara, three to five players challenge the rushing waterfalls } \\
\text { while trying to collect precious gems that are alongside the } \\
\text { river. }\end{array}$ & paraíso & \\
\hline
\end{tabular}




\begin{tabular}{|c|c|c|}
\hline $\begin{array}{l}\text { Many first-rate books by women and about women's lives never } \\
\text { find a way to escape "Women's Fiction". }\end{array}$ & ent & \\
\hline $\begin{array}{l}\text { Understanding women's fiction is important to succ } \\
\text { crafting a novel and submitting the work to the right pu }\end{array}$ & & wome \\
\hline
\end{tabular}

\section{BIONOTES / NOTAS BIOGRÁFICAS}

Ana Rojo is Associate Professor in Translation at the University of Murcia, Spain, where she has chaired the Translation and Interpreting Department for five years. Dr Rojo is currently Coordinator of the Master in Translation for the Publishing Industries and Chair of the PhD Commission. Her main areas of research are in Translation and Cognitive Linguistics. She has authored or co-edited Contrastive Cognitive Linguistics (University of Murcia, 2003), Cognitive Linguistics: From Words to Discourse (University of Murcia, 2007), Step by Step. A Course in Contrastive Linguistics and Translation (Peter Lang, 2009), Trends in Cognitive Linguistics (Peter Lang, 2009), Cognitive Linguistics and Translation: Advances in Some Theoretical Models and Applications (Mouton de Gruyter, 2013), Diseños y Métodos de Investigación en Traducción (2013). She has also published scholarly articles in specialized journals such as Livius, Sendebar, Babel, Languages in Contrast, Meta, Across Languages and Cultures and also book chapters in edited volumes by publishers such as Atrio, Anubar, Mouton de Gruyter, John Benjamins.

Ana Rojo es Profesora Titular en el Departamento de Traducción e Interpretación de la Universidad de Murcia, que ha dirigido durante cinco años. Actualmente coordina el Máster en Traducción Editorial y preside la Comisión de Doctorado. Sus principales líneas de investigación comprenden la traducción y lingüística cognitiva. Ha sido autora o co-editora de Contrastive Cognitive Linguistics (Universidad de Murcia, 2003), Cognitive Linguistics: From Words to Discourse (Universidad de Murcia, 2007), Step by Step. A Course in Contrastive Linguistics and Translation (Peter Lang, 2009), Trends in Cognitive Linguistics (Peter Lang, 2009), Cognitive Linguistics and Translation: Advances in Some Theoretical Models and Applications (Mouton de Gruyter, 2013) y Diseños y Métodos de Investigación en Traducción (2013). También ha publicado numerosos trabajos en revistas como Livius, Sendebar, Babel, Languages in Contrast, Meta y Across Languages and Cultures, o como capítulos de libros en editoriales como Atrio, Anubar, Mouton de Gruyter, y John Benjamins. 
Marina Ramos studied Translation and Interpreting at the University of Granada, with a focus on German and English translation. In 2009, she completed a Master in English Linguistics at the University of Murcia, Spain, with a research project about cognitive linguistics. Since then, she has been lecturing Translation at the University of Murcia. In October 2013, she defended her $\mathrm{PhD}$ dissertation on the emotional impact of audio description. Dr. Ramos has been awarded several grants and fellowships and has presented her research in different international conferences.

Marina Ramos estudió Traducción e Interpretación en la Universidad de Granada (alemán e inglés). En 2009 obtuvo el título de Máster en Lengua y Lingüística Inglesas de la Universidad de Murcia. Desde entonces, imparte docencia en el Grado y Máster en Traducción e Interpretación en esa universidad. En octubre de 2013, defendió su tesis doctoral sobre audiodescripción. La Dra. Ramos ha recibido diferentes becas de investigación y ha participado en numerosos congresos internacionales. 